\title{
THE JOURNAL OF THE
}

\section{DEPARTMENT OF AGRICULTURE AND LABOR}

\author{
OF \\ PORTO RICO
}

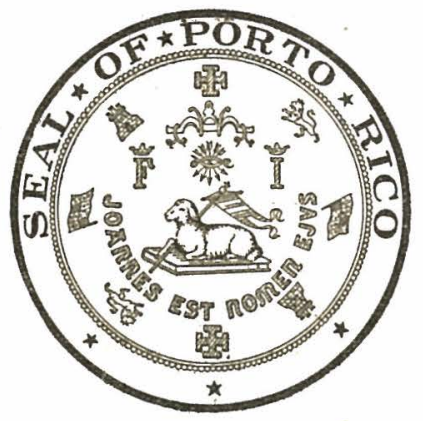

THE STATUS OF ENTOMOLOGY IN PORTO RICO

BY

GEORGE N. WOLGOTT

Entomologist.

PUBLISHED BY

THE INSULAR EXPERIMENT' STATION

RIO PIEDRAS, P. R. 


\title{
THE STATUS OF ENTOMOLOGY IN PORTO RICO. ${ }^{1}$
}

\author{
By George N. Wolcott.
}

Porto Rico is an oblong island, 100 miles long and 35 broad, farther east than Maine and farther south than Cuba, which belongs to, or rather, is a part of the United States. Porto Ricans are citizens of the United States, and as such, many of their young men served in the World War.

Whatever the authenticity of Columbus' reputed reply to Queen Isabella as to what kind of country was the Island of Porto Rico he had discovered, which consisted of crumpling up a sheet of paper and declaring it looked like that, it nevertheless has a sound basis as giving an accurate idea of the Island's topography. As one approaches from the ocean, the jagged skyline of the mountains looks as sharp and pointed as the teeth of a saw, and in crossing the Island by any of the several highways one would think that it consisted entirely of mountains. Around the coast and in the river valleys, however, is a considerable area of level land, mostly at the present time devoted to the growing of sugar cane, or possibly more profitably with milk at 18 or 22 cents a quart, in pasturage. Despite the steepness of the mountains, the density of the agricultural population demands that they be under cultivation, and the lower slopes, and sometimes even the higher peaks in the eastern and central sections of the interior are covered with great cheese-cloth sheds under which tobaceo is growing, or are marked off with hedges of gandules or wild pineapples into sweet-potato patches. Sugar cane is also grown on the steep slopes, some of it being ground in small mills hidden away in the mountains, but most of it transported by bullcarts or auto trucks to railroad loading stations and shipped to the big mills along the coast. The mountainous sections of the western part are almost exclusively devoted to coffee growing, and small patches of coffee are found at the lower levels. There are a large number of wild or rather volunteer orange trees interspersed with

1 This paper was seheduled for presentation at the Thirty-Fourth Annual Meeting of the American Association of Economic Entomologists at Toronto, Canada, Dec. 31, 1921, but due to the absence of Mr. Wolcott, was presented only by title. 
the coffee, but the commercial grapefruit industry, mostly in the hands of continental Americans, is largely concentrated in a belt along the north coast between Carolina and Arecibo. Many of the Americans are also growing pineapples, especially around Río Piedras and Manatí. In the comparatively dry northwestern corner of the Island is a rather considerable area in cotton. Of these crops, sugar cane is easily first, having been greatly stimulated by war prices for sugar; tobacco second; . coffee, due to continued low prices, a dwindling third; grapefruit a stationary fourth, and oranges, pineapples, cotton and cocoanuts of minor importance.

Although the Luquillo mountain range, in the north-eastern part of the Island, has possibly the highest and certainly the most notable peaks, the most continuous ranges of mountains are near the southern coast, and as the rainfall-bearing trade winds are from the northeast, most of the Island receives an abundance of rainfall. The narrow strip of alluvial land along the south coast, which seldom receives more than thirty or forty inches of rainfall, and in some years less than twenty inches, is most fertile, and with the aid of extensive irrigation from the mountain watershed and artesian wells, is under a high state of cultivation and almost entirely devoted to the growing of sugar cane.

The agriculture of Porto Rico has not changed greatly since the landing of the United States soldiers, for with the exception of the grapefruit groves planted by the Americans, the same crops are grown now that were cultivated for many generations before, although the acreage devoted to coffee has dwindled and that to sugar cane has greatly increased. Yet except for Don Manuel Fernández Umpierre and Don Fernando López Tuero, agriculturists who wrote on the cultivation of sugar cane and incidentally dealt with a few of its important insect pests, and the naturalists, Andrés Pedro Ledrú, a Frenchman, Dr. Juan Gundlach, a German-Cuban, and Dr. Agustín Stahl of Bayamón, P. R., who in cataloging the fauna and flora of the Island noted some of the more obvious insects, Entomology, and more especially the Economic Entomology of these crops, did not exist before the establishment of the Federal Experiment Station at Mayagüez. The first Entomologist appointed was Mr. O. W. Barrett, and his excellent paper (Bulletin No. 2, P. R. Agr. Expt. Sta.) on the changa was the best on this insect up to the appearance of the bulletin by Mr. Van Zwaluwenburg (Bulletin No. 23, P. R. Agr. Expt. Sta.) The second Entomologist, Mr. W. V. Tower, issued a bulletin (Bulletin No. 10, P. R. Agr. Expt Sta.) on the "Insects Injurious to Citrus Fruits and Methods for Combatting them," which although 
a little out of date, is still the best and indeed almost the only publication on these insects. Through the efforts of Mr. Tower, beekeeping has been developed from a small nucleus to a very considerable industry, especially around Mayagüez and in the coffee districts. Several circulars have been published and Dr. Phillips of the United States Bureau of Entomology made a survey in 1913 ("Porto Rican Beekeeping," Bulletin No. 15, P. R. Agr. Expt. Sta.).

The MIayagüez Station was mainly interested in the introduction of new crops, the rotation of crops and new systems of agriculture, and in the problems of the American citrus growers, but there were many problems dealing with the major crops of sugar cane and tobacco that demanded solution, to which only passing attention could be given. A few American cane growers who had worked in Hawaii, favored the establishment of an experiment station to be devoted entirely to sugar cane, similar to the one in Hawaii, and ably seconded by some Porto Ricans who owned large centrals, eventually all the cane growers united to establish such a station at Río Piedras. The first Entomologist appointed, Mr. D. L. Van Dine, trained at Cornell and with previous experience in Hawaii and Louisiana, was a man of broad vision and delightful personality, able to effectively organize the machinery of men and equipment for the investigation of the problems to be solved. His reports on the insects of sugar cane, and those on individual insects which later to some extent superseeded them, by his assistants, each of whom in turn became Entomologist at this Station, testify to his comprehension of the problems presented. The Sugar Growers' Station failed of continued support after the departure of some of the men primarily responsible for its establishment, and it was then taken over by the Insular Government and renamed the Insular Station to distinguish it from the Federal Station at Mayagüez, and its field broadened to include all the agricultural interests in the Island. Thus at present there are two experiment stations in Porto Rico, with no sharply differentiated fields of usefulness.

The tobacco growers did not organize an experiment station, but through the Board of Commissioners of Agriculture, Mr. S. S. Crossman was employed to work on their insect problems, primarily the changa, and secondarily those of other insects. It was due to his efforts that a thoroughly satisfactory and effective method of destroying the changa was discovered, which is now extensively used throughout the tobacco districts.

Little was known about the food of birds in Porto Rico and through a co-operative arrangement with the United States Bureau of 
Biologic Survey, Mr. Alex. Wetmore was detailed to make an extended survey to determine the relation of the Island birds to the insect fauna. His excellent report, covering a period of field work of nine months, entitled "Birds of Porto Rico," (Bull. No. 326, U. S. Dept. Agr., or Bull. No. 15, Bd. Comm. Agr. P. R.) is in large part of entomological content, despite its ornithological title.

The Board also organized a Plant Quarantine Inspection Service and Mr. W. V. Tower was appointed Chief Inspector.

The years 1912-14 probably mark the high tide of entomological work in Porto Rico, with Dr. C. W. Hooker at Mayagüez working on coffee insects, and a little later, Mr. R. H. Van Zwa'uwenburg; Mr. 'D. L. Van Dine and Mr. Thos. H. Jones at Río Piedras working on sugar-cane insects; Mr. S. S. Crossman at Aibonito working on tobaces insects; Mr. E. G. Smyth at Guánica working on the white grubs (Lachnosterna spp., especially L. vandinei Smyth) attacking sugar cane, with Mr. C. E. Hood, and later Mr. G. N. Wolcott, in Illinois, collecting parasites of them; and with Mr. W. V. Tower in charge of the Plant Quarantine. Of these men, only the two latter are still in Porto Rico, and this tendency of practically all scientists who have been in the Island to remain for only a year or two, or three or four at most, leaving before they are much more than thoroughly familiar with it and the problems in their line, is one of the points of greatest weakness in all the research that has been done. In the last few years, men born in Porto Rico and receiving their early education there, but completing it in the States, have been forging to the front in all lines of science, the most illustrious representative in Entomology being Mr. Francisco Seín Jr. (Cornell, '20), now an assistant at the Insular Station.

The "changa" or Porto Rican mole-cricket, Scapteriscus vicinus Scudder, is as much the famous and characteristic insect of Porto Rico, as the bibijagua, Atta insularis Guerin, is of Cuba, the cotton boll weevil is of Mexico, the cattle tick is of Texas, or the potato beetle is of Colorado. Your fellow passenger on the steamship, otherwise devoid of entomological information, will dilate at length on the ravages of the changa in tobacco plantations and vegetable gardens, when you mention that you are interested in insects. Yet it is now of comparatively minor importance, at least to the tobaceo growers, mainly through the work of Mr. Crossman, who devised the 2-3 pounds Paris Green and one hundred pounds flour mixture, which applied as a powder in a ring around young plants will effectually protect them, or slightly moistened so that the flour holds together in little chunks, and scattered about on freshly plowed and 
harrowed land, will kill the changas before the crop is planted. There are three flea-beetles of tobaceo, Epitrix cucumcris Harris, E. parvula Fabr., and Systena basalis J. Duva!; several cutworms, especially Feltia annexa Treit., besides the hornworm, Phlegethontius sexta jamaicensis Butler; a looper, Syngrapha egena Guenee and a leaf-folder, Pachyzanela periusalis Walker, all pests of more or less importance and all alike susceptible to control by dusting the plants with arsenate of lead. The control of tobacco insects is a chapter of successes for the economic entomologist, but largely because of the nature and the value of thr crop, which makes the application of expensive insecticides and the use of hand labor both practical and profitable. Only one insect of tobaceo, the splitworm, Phthorimaea operculella Zeller, which is yearly increasing in importance in all the dryer tobacco districts and apparently was not present in the Island several years ago, is the exception. Largely because its injury somewhat resembles that of the leaf-folder, it was not recognized by the growers as a distinct pest, but later it has been specifically observed as "candela" or fire, and the problem of getting them to try out hand destruction of the caterpillars in their mines, and the destruction of solanaceous weeds and volunteer tobaceo, which furnish alternate hosts out of tobacco season, will be simplified. The destruction of the alternate host plants would possibly considerably reduce the abundance of practically all the other tobacco insects, except the changa, and might even avoid the necessity of applying poison, yet it has never been attempted even by the best informed and most intelligent growers.

The most important pest of sugar cane, not only in Porto Rico, but throughout the Americas, is the moth stalk borer, Diatraea saccharalis Fabr. Despite all the attention given to this insect, much yet remains to be done and really effective methods of control discov. ered. At present the practical recommendations for partial control in Porto Rico are quite the opposite of what one might imagine and consist of (1) to not burn trash (mostly dead leaves) in the field after the crop is harvested, and (2) to plant infested seed (tops of the cane stalk). Infested seed should be planted, as this is the easiest way of eliminating one source of infection for the young plant cane. The moth can ordinarily not emerge from seed which is covered by even so little as an inch of soil, while if clean seed is selected, the discarded (infested) seed is invariably left at the edge of the field where the moths have no difficulty on emergence in ovipositing on the young shoots that are coming up from the healthy seed that was planted. The pile of discarded seed might 
be burned, and sometimes it is when it gets dry enough, but that is after the moths have emerged. The recommendation not to burn trash is sound because burning destroys the common egg parasite Trichogramma minutum Riley, and the recently discovered black egg parasite Prophanumus alecto Crawford, and its effectiveness (except for one variety of cane, Crystalina) has been proven by many counts of mature cane. It has also been found that several varieties of cane, Yellow Caledonia, Cavengerie or Red Cane (not Kavangire or Uba) and B 4312 are less infested by the borer than other varieties.

White grubs (Lachnosterna spp.) are the most destructive pests of cane in certain restricted localities and are of more or less importance to many other crops. Mr. E. G. Smyth worked exclusively on the white grubs at Guánica for several years and continued his investigations up to the past year. Yet none of his recommendations have been adopted by the cane growers most interested and they have even temporarily discontinued the hand collection of grubs after the plow, and of beetles feeding on the cane leaves at night. This is partly due to the introduction of new varieties of cane with a more vigorous root system, and partly to the increased labor cost.

Another angle of attack on the white grub problem was by the importation of insect parasites from the United States, as none occur where the grubs are most abundant. This was continued for a period of over three years, and resulted in several thousand cocoons of various species of Tiphia being sent to Porto Rico, besides small numbers of other parasites. Up to the present year it was thought that the parasite introduction was a failure, but recently Tiphia wasps have been found in the region where releases were made. Mr. S. A. Rohwer believes that the specimens submitted for his examination represent a new species, although very similar in many respects to some of the introduced species.

There are several other pests of sugar cane which do considerable damage; a weevil root borer, Diaprepes spengleri Linn., a rhinoceros beetle, Strataegus titamus Fabr., a weevil rotten stalk borer, Metiamasius hemipterus Linn., several mealybugs, Pseudococcus sacchari Ckll., P. calceolariae Mask., and P. brometiae Bouche, a yellow aphis, Sipha flava Forbes, besides a large number of others of minor importance, but from none of these is the damage ordinarily sufficient to repay the cost of any control measure which might be used.

The ditinguished botanist and specialist in tropical agriculture, Mr. F. S. Earle, who eame to Porto Rico to study the mosaic disease of sugar cane, caused to be initiated the extensive investigations on the relation of insects to its transmission. Despite all the work which 
has been done, no conclusive results have yet been obtained to show that any cane insect transmits the disease in the field. ${ }^{1}$

The insects of sugar cane are difficult to control, either because the damage caused is indirect or difficult to effectively demonstrate, and growers will ordinarily disregard it, or, in the case of the white grubs and weevils, hand collection is costly and serves only as a. fairly effective insurance for the next crop. In the case of the insects of coffee, the situation is aggravated by the continued low price of the crop, added to the fact that the more injurious insects would be difficult to control even if expense were secondary. The coffee leafminer, Leucoptera coffeella Stain., is a small caterpillar living entirely within the leaf, which spins its cocoon on the underside of the leaf and emerges as a minute satiny white moth. There is a wide variation in abundance of the miner at different seasons, elevations, and under varying conditions of shade and exposure to the wind, but there appears to be no constancy in this variation, and it is possibly largely the effect of parasites, at least four of the larva being known.

The small, dark brown, Otiorhynchid beetles, Lachnopus coffeae Marshall ${ }^{2}$ which feed on the tender leaves and buds of coffee, lay their eggs between the leaves, and the grubs on hatching, drop to the ground, where they feed on roots. These beetles are especially abundant and destructive around Adjuntas, and were first recorded from there as "La Plaga de la Vaquita" in 1895 by Sr. G. Quintanilla. When occuring in destructive abundance, especially in the late spring, hand collection of the beetles might prove profitable.

Two ants, "hormiguilla" and "albayalde", in the opinion of the coffee-grower are the important insects in the coffee groves, as may be judged by their having received specific common names. The former, which Prof. Wheeler has described as the subspecies ramulorum of Myrmetachista ambigua Forel, a medium-sized blue-black ant with reddish-brown thorax, hollows out tunnels in the trunks of the coffee shade trees, and later attacks the coffee trees, causing roughened hypertrophies where the branches come out, which are points of weakness where the trees break when the berries are being picked. The cutting out and destroying of old shade trees and their replacement by younger and possibly others kinds of trees is effective

1 The finding of winged Aphis maidis Fitch on young cane that had just been weeded gave the elue to how this aphil, which does not normally occur on cane, but rather on the smaller grasses common in cane fields, might be forced on to sugar-cane and be the vector of mosaic disease. The experiments conducted by $\mathrm{Mr}$. Carlos E. Chardón indicate that this aphis of malojillo and other grasses, and Carolinaia cyperi Ainslie of Cyperus rotundus, a common sedge in cant: fields, do transmit the disease.

${ }^{2}$ Marshall, Guy A. K., "Some Injurious Neotropical Weevils" in Bull. Ent. Research Vol. 13, pt. 1, pp. 59-77, pl. 2, May 1922. 
in eliminating this ant, but the cost is considerable. ${ }^{1}$ The latter, Wasmannia auropunctata Roger, a very small yellow ant, bites viciously and is annoying to the coffee pickers.

Large beetle borers, Apate francisca Fabr., and the caterpillars of a Cossid moth sometimes attack a few trees in a grove and cause the owner much excitement, although the destruction of the infested portions of the trees eliminates the danger of the spread of an infestation.

About a decade ago Alabama argillacea Hübner was a serious pest: of cotton for a series of years, entirely defoliating the plants and necessitating the extensive use of spray pumps for the application of poisons by the commercial growers, but due to extensive parasitism by Chalcis incerta Cresson and Sarcophaga sternodontis Towns., no recent outbreaks have occurred. During the last few years the only leaf-feeding caterpillar to be found on cotton has been Anomis doctorium Dyar. The cotton leaf blister mite, Eriophyes gossypii Banks, is often found on tree cotton, but seldom does much damage in commercial fields. The important pest of cotton is the pink bollworm, Pectinophora gossypiella Saunders, of which a light infestation has been found in the cotton district, and occassionally heavily infested trees noted in other parts of the Island. A vigorous campaign is being conducted against this pest, using methods of control which have been developed elsewhere. As all cotton is ginned at a single gin, the problem of supplying clean (fumigated) seed is comparatively simple and the growers are being instructed to collect and burn all trash in the fields, plow immediately, and to destroy wild and volunteer cotton plants. Search is being made to discover the caterpillars in other host plants, as one has been found in an okra pod. By a fortunate coincidence, a former employee of the Federal Horticultural Board, Mr. J. D. More, who had extensive experience with the pink bollworm in Texas, was employed at the Insular Station at the time of its discovery in Porto Rico, and has proved invaluable in dealing with this pest.

The citrus insects of Porto Rico have been adequately treated in an early publication by Mr. Tower. Later he was largely responsible for the introduction and popularization of the paraffin oil spray for citrus scales which Mr. Yothers had perfected in Florida.

1 Baits of finely ground meat, thoroly mixed with powdered potassium or sodium cyanide in proportions varying from 15 to 1 , to 30 to 1 , and promptly thereafter placed in small bits modeled like little shelves in cracks and rougnesses of the bark immediately underneath places where the ants are most abundant, will kill large numbers of them. The action of the hydrocyanic acid gas set free by the organic acids of the meat, is prompt, and ils a few minutes the little shelves will be covered with heaps of dead ants. Experiments now in progress indicate that calcium cyanide is equally, or even more effective, and the powder can be applied with a dust-gun, rather than mixed with meat. 
The "Insects Attacking Vegetables in Porto Rico" have been admirably treated by Mr. R. T. Cotton in a paper of that name (Jour. Dept. Agr. P. R., Vol. 2, Oct., 1918), to which one constantly refers because of the completeness, accuracy and succinctness of its information.

Most of the entomological work here summarized has been done in the last ten years, and considering all the difficulties encountered, constitutes a not unworthy record of progress and achievement.

$0-0-0$ 